\title{
Counter Anion Directing Structure Control: An Anionic 3D Open Framework with a Diamond Network Structure Comprising of 1,4-Cyclohexanedicarboxylic Acid
}

\author{
Minyoung Yoon, Joongpyo Shim, ${ }^{\dagger}$ and Gyungse Park ${ }^{\ddagger}$ \\ Department of Nanochemistry, College of Bionano, Gachon University, Sungnam 461-701, Korea \\ 'Department of Nano \& Chemical Engineering, Kunsan National University, Kunsan 573-701, Korea \\ "Department of Chemistry, Kunsan National University, Kunsan 573-701, Korea. "E-mail: parkg@kunsan.ac.kr \\ Received April 1, 2014, Accepted May 16, 2014
}

Key Words : MOF, Diamond network, 1,4-Cyclohexanedicarboxylic acid, Anionic framework

Coordination polymers (CPs) are a kind of inorganic and organic hybrid polymer materials formed by self-assembly process. Metal-organic frameworks (MOFs) are a kind of porous coordination polymer comprising metal ions and ligands with a finite porous structure. ${ }^{1,2}$ Unlike common porous materials such as Zeolite various combinations of metal ions and ligands allow to synthesize lots of MOFs with different structures. ${ }^{3}$ In addition, functionalization of the frameworks allows fine tuning of physical properties of MOFs for their applications. In the light of growing interests on MOFs as materials for storage, ${ }^{4}$ separation, ${ }^{5}$ sensing, ${ }^{6}$ catalysis $^{7}$ and transport, ${ }^{8}$ considerable efforts have been devoted to achieve custom designed internal environments of pores or channels in MOFs.

Recent efforts in MOF researches are mainly devoted to their applications, developing a new synthetic strategy for MOF synthesis is still one of the most important issues because a structure of the materials directly related to a property of the materials. Yaghi and coworkers recently developed and summarized the design strategy of MOFs depending on the coordination geometry of metal ions and the shape of a ligand, which is known as reticular chemistry. ${ }^{3}$ In addition, the other reaction conditions, such as solvents and reaction temperatures, often affect the structure of resulting MOFs. ${ }^{9}$ Nonetheless, controlling the structure of MOFs by counter anions of a metal salt is rarely reported. Herein, we report a new anionic $3 \mathrm{D}$ open metal-organic framework, $\left[\mathrm{NH}_{2}\left(\mathrm{CH}_{3}\right)_{2}\right]_{2} \cdot\left[\mathrm{Cd}(\mathrm{chdc})_{2}\right]$ (chdc $=1$,4-cyclohexanedicarboxylic acid), in which a structure was directed by using the different counter anion of the metal salt.

A rigid ligand such as terephthalic acid has been widely employed as a linker to construct a rigid framework, whereas several MOFs comprising a flexible ligand such as fumarate have also been reported. ${ }^{10}$ Among many flexible ligands 1,4chdc- $\mathrm{H}_{2}$ offers an unique opportunity for construction of MOFs because it has not only good bridging ability but also flexible motion of the ligand. ${ }^{11}$ The flexible nature of 1,4chdc- $\mathrm{H}_{2}$ allows three unique isomer structures (Scheme 1) depending on the environment. By combination of various conformations of 1,4-chdc- $\mathrm{H}_{2}$ and metal ions, numerous MOF structures have been reported. Recently, we have reported a new 3-D MOF, $\left[\mathrm{Cd}_{2}(\mathrm{chdc})_{2} \cdot \mathrm{DMF}\right]$ (1), compri- sing two conformational isomers of 1,4-chdc, e,e-trans-chdc and a,a-trans-chdc, in different molar ratio (3:1). ${ }^{12}$ However, we observed that the change of the counter anion of the metal salt produces MOF comprising only e,e-trans-chdc conformation which is thermodynamically more stable than a,a-trans-chdc. In addition, it should be noted that the resulting framework $\left[\mathrm{NH}_{2}\left(\mathrm{CH}_{3}\right)_{2}\right]_{2} \cdot\left[\mathrm{Cd}(\mathrm{chdc})_{2}\right]$ (2) is an anionic framework containing counter cations in the pore of the framework with a diamond net topology.

\section{Results and Discussion}

A MOF comprising both e,e-trans-chdc and a,a-transchdc conformation, $\left[\mathrm{Cd}_{2}(\mathrm{chdc})_{2}\right] \cdot \operatorname{DMF}(\mathbf{1})$, was prepared by a solvothermal reaction of cadmium nitrate salt and the ligand, 1,4-chdc. However, adopting a different metal salt, cadmium acetate, results in the formation of a new MOF composed of only e,e-trans-chdc conformation, $\left[\mathrm{NH}_{2}\left(\mathrm{CH}_{3}\right)_{2}\right]_{2}$. $\left[\mathrm{Cd}(\mathrm{chdc})_{2}\right]$ (2). The structure of $\mathbf{2}$ was determined by X-ray crystallography using Siemens CCD X-ray diffractometer. The crystal data and structure refinement for complex $\mathbf{2}$ are summarized in Table 1.

$\mathrm{X}$-ray structure of $\mathbf{1}$ and $\mathbf{2}$ clearly shows the difference of both frameworks. Ligand conformation analysis suggested that 1 adopts two conformations of the 1,4-chdc ligand, e,etrans and a,a-trans but 2 compose only e,e-trans conformation ligand. To study the ligand conformation difference in framework 1 and 2, Gibbs free energy $(\Delta G)$ of three conformations was calculated (Scheme 2). The Gibbs free energy suggests that $\mathbf{2}$ might be more favorable MOF structure than $\mathbf{1}$ because of smaller Gibbs free energy of $e, e$ trans conformation. However, it is difficult to say that $\mathbf{2}$ is

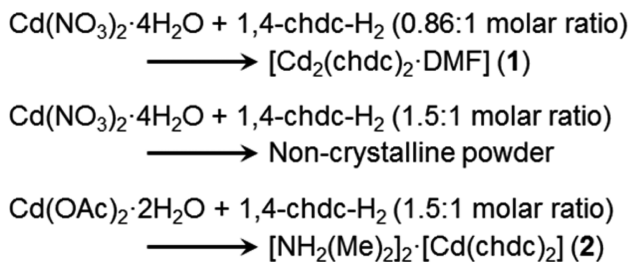

Scheme 1. Control of MOF structure by changing of the counter anions of metal salts. 
Table 1. Crystal data and structure refinement for $\left[\mathrm{NH}_{2}\left(\mathrm{CH}_{3}\right)_{2}\right]_{2}$. $\left[\mathrm{Cd}(\mathrm{chdc})_{2}\right](\mathbf{2})$

\begin{tabular}{lll}
\hline Empirical formula & $\mathrm{C}_{16} \mathrm{H}_{16} \mathrm{CdO}_{8}$ & \\
Formula weight & 448.69 & \\
Temperature & $223(2) \mathrm{K}$ & \\
Wavelength & $0.71073 \AA$ & \\
Crystal system & Orthorhombic & \\
Space group & $F d d d$ & $\alpha=90^{\circ}$ \\
Unit cell dimensions & $a=11.187(1) \AA$ & $\beta=90^{\circ}$ \\
& $b=21.217(1) \AA$ & \\
& $c=21.241(1) \AA$ & \\
Volume & $5041.5(6) \AA^{\circ}$ & \\
$Z$ & & \\
Density (calculated) & $1.182 \mathrm{Mg} / \mathrm{m}^{3}$ & \\
Absorption coefficient & $0.894 \mathrm{~mm}^{-1}$ & \\
Theta range for data collection & 2.27 to $28.21^{\circ}$ \\
GOF $_{\text {Final R indices }[I>2 \sigma(\mathrm{I})]^{a}}$ & 0.985 \\
& $R_{1}=0.0657, w R_{2}=0.1840$ \\
$R$ indices (all data) & $(\mathrm{squeezed})$ \\
\hline
\end{tabular}

${ }^{a} R_{1}=\Sigma|| F_{\mathrm{o}}|-| F_{\mathrm{c}}|/ \Sigma| F_{\mathrm{o}} \mid . w \mathrm{R}_{2}=\left[\Sigma w\left(\left|F_{\mathrm{o}}{ }^{2}\right|-\left|F_{\mathrm{c}}{ }^{2}\right|\right)^{2}\right] / \Sigma\left[w\left|F_{\mathrm{o}}\right|^{2}\right]^{1 / 2}$.

the thermodynamically stable structure than $\mathbf{1}$ because of the small energy difference between two conformations $(\Delta \Delta \mathrm{G}=$ $2.7 \mathrm{~kJ} / \mathrm{mol}$ ).

The MOF 1 prepared using a nitrate salt was constructed from tri-nuclear SBUs which contain three crystallographically non-equivalent six-coordinated cadmium centers. (Figure 1(a)) Three cadmium metal ions are connected by 1,4-chdc with a 1:1 ratio resulting in the formation of a neutral framework. However, the framework 2 comprising a single eight-coordinated cadmium metal center was prepared using the acetate salt (Figure 1(b)). Two oxygen atoms on a carboxylate functional group were coordinated asymmetrically on cadmium metal ion with bond distances of $2.378 \AA$ and $2.513 \AA$ for $\mathrm{O} 1$ and $\mathrm{O} 2$, respectively (Figure 2). The four symmetrical 1,4-chdc ligands coordinated on the cadmium centers of $\mathbf{2}$ without any coordinated solvent make the framework a distorted dodecahedron geometry. The details of bond lengths $(\AA)$ and bond angles $\left({ }^{\circ}\right)$ for 2 are summarized in Table S4. Interestingly, the high coordination number of an anionic ligand on the metal ion makes a 1:2 metal to ligand ratio for 2 allowing the formation of the anionic framework. Although $\mathbf{2}$ is the anionic framework, the counter cations in $\mathbf{2}$ were not clearly identified in the crystal structure because of severe disorder of the dimethylammonium cation, which is common in anionic framework. ${ }^{13}$ However, X-ray crystal structure and elemental analysis suggests that the existence of the dimethylammonium cation. Network topology analysis shows that the 3D structure of 2 has a diamond net topology (Figure 3). Although diamond net is a common topology in $3 \mathrm{D} \mathrm{MOF}$ structure, it is unusual to have the diamond topology in the anionic MOF filled with the cations in the pores. Connolly surface in Figure 4 shows accessible void space of $2(36 \%)$. In spite of the presence of the void space in $\mathbf{2}$, the dimethylammonim cation filling the void space of $\mathbf{2}$ makes it almost a non-porous material, which was proved by $\mathrm{N}_{2}$ gas sorption experiment. However, it is expected that the tight filling of the cations inside of the channels can give an opportunity for an application as a proton conducting material.
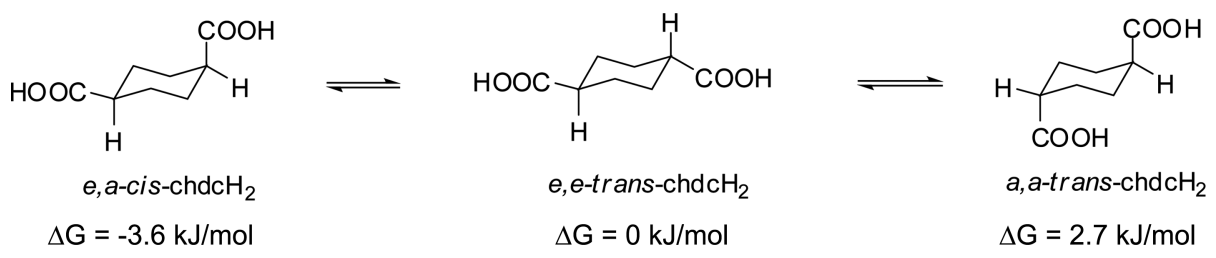

Scheme 2. Energies and structures of three possible conformations of 1,4-chdc- $\mathrm{H}_{2}$.

(a)

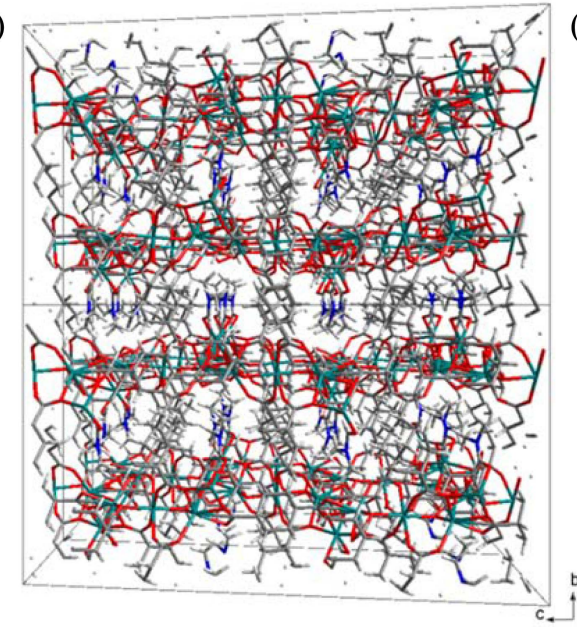

(b)

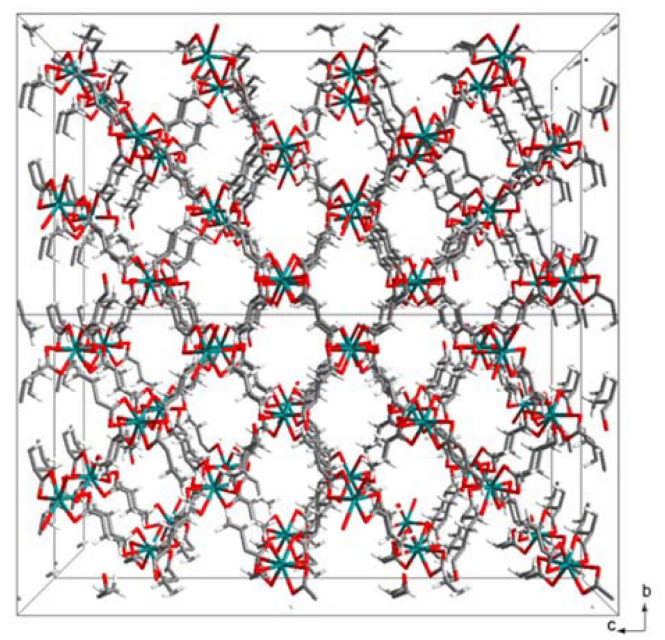

Figure 1. Framework structures of (a) 1 and (b) 2. 


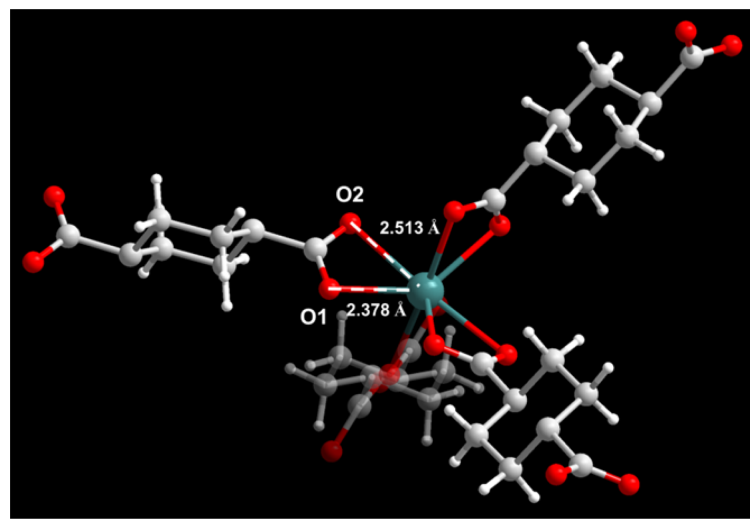

Figure 2. Ligand conformation (e,e-trans) on the cadmium ion of 2 .

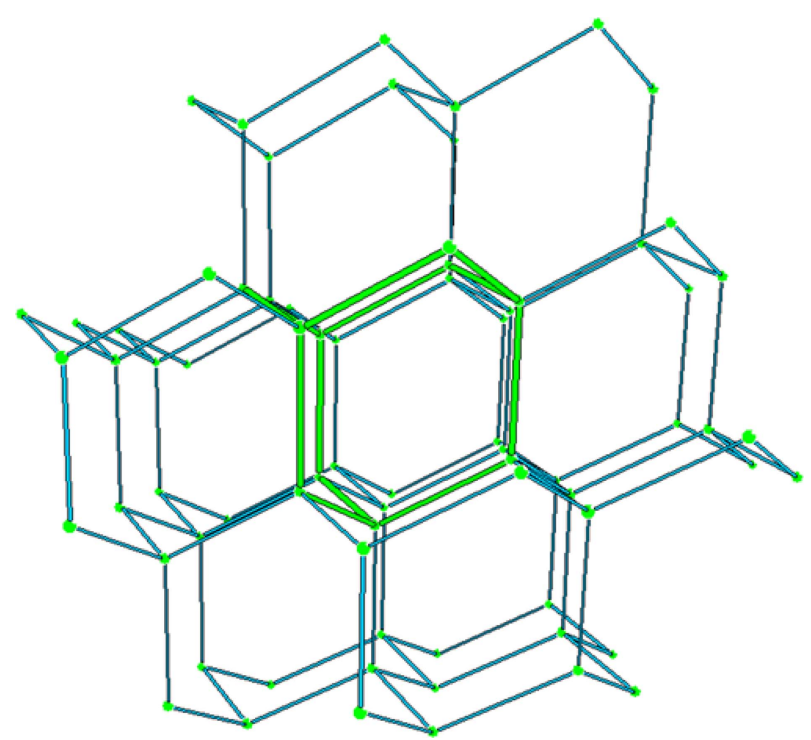

Figure 3. Diamond network (dia) structure of 2.

To understand the reason of the structural difference of $\mathbf{1}$ and $\mathbf{2}$, reaction conditions for $\mathbf{1}$ and $\mathbf{2}$ was very carefully compared. The major differences of the reaction conditions were use of the counter anions and the metal to ligand ratios. Low metal to ligand ratio $(0.86: 1)$ in the presence of the nitrate ion gives neutral framework 1, whereas high metal to ligand ratio (1.5:1) with the acetate counter anion allows formation of the anionic framework 2 . It should be noted that in spite of high metal to ligand ratio (1.5:1), we cannot obtain the framework 2 with the cadmium nitrate suggesting an important role of the acetate anion in structure determination. Conjugated acid and base property of the salt makes nitrate and acetate salt different behavior ( $\mathrm{pH}$ value of aqueous metal salt solutions is summarized in Table S1.), where the acetate salt has higher $\mathrm{pH}$ than nitrate salt. Higher $\mathrm{pH}$ of the acetate salt solution probably produce more $\mathrm{OH}^{-}$ ions facilitating decomposition of DMF by a nucleophilic attack of $\mathrm{OH}^{-}$and produces more dimethylammonium cation which can direct formation of the anionic framework.

In summary, we successfully demonstrated controlling the MOF structure by changing the counter anions of the metal

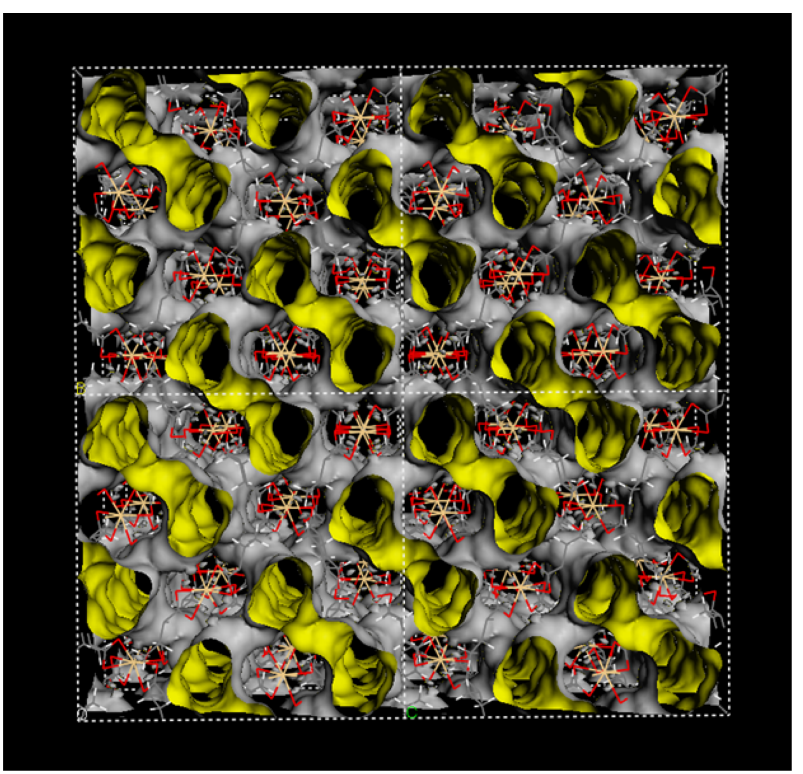

Figure 4. Connolly surface area of 2 after removal of counter anions filling the pores.

salts. The nitrate salt and acetate salt give different $\mathrm{MOF}$ structures, $\left[\mathrm{Cd}_{2}(\mathrm{chdc})_{2} \cdot \mathrm{DMF}\right]$ (1) and $\left[\mathrm{NH}_{2}\left(\mathrm{CH}_{3}\right)_{2}\right]_{2} \cdot[\mathrm{Cd}-$ (chdc) $)_{2}$ (2), respectively. The acetate salt usually has higher $\mathrm{pH}$ than the nitrate salt producing more $\mathrm{OH}^{-}$. Strong nucleophile, $\mathrm{OH}^{-}$, facilitates decomposition of DMF and produces more dimethylammonium which directs formation of the anionic framework. New 3D MOF 2 has four chdc ligands with only e,e-trans conformation on the cadmium metal ion resulting in the 3D anionic framework. Interestingly, the topology of $\mathbf{2}$ is the diamond net which is rare in the anionic frameworks. Although pores of $\mathbf{2}$ were not accessible because of the counter cations filling the pores, the dimethylammonium ion may act as a proton conducting material in the absence of water. Such a framework may find useful applications in high temperature proton conducting materials. Work along this line is in a progress for high temperature proton conduction.

\section{Experimental Section}

Materials and Methods. All the chemicals were purchased from Aldrich and used as received without further purification. Gas sorption isotherm was measured on Quantachrome Autosorb-1.

Synthesis of $\left[\mathrm{NH}_{2}\left(\mathrm{CH}_{3}\right)_{2}\right]_{2} \cdot\left[\mathrm{Cd}(1,4-c h d c)_{2}\right]$ (2). A mixture of $\mathrm{Cd}(\mathrm{OAc})_{2} \cdot 2 \mathrm{H}_{2} \mathrm{O}(68 \mathrm{mg}, 0.26 \mathrm{mmol})$ and trans-1,4chdc (30 mg, $0.17 \mathrm{mmol}$ ) was suspended in DMF (1.3 mL), placed in a sealed-glass tube, and heated at $80{ }^{\circ} \mathrm{C}$ for 3 days. Upon cooling to room temperature, the colorless crystalline was formed, collected by filtration, washed with DMF, and dried under a reduced pressure at room temperature for $5 \mathrm{~h}$ to give the product $(0.212 \mathrm{~g}, 56 \%)$. Elemental Analysis Calcd. for $\mathrm{C}_{20} \mathrm{H}_{32} \mathrm{~N}_{2} \mathrm{O}_{8} \mathrm{Cd}$ : C, 44.41; H, 5.96; N, 5.18; Found: C, 44.25; H, 5.76; N, 5.26.

Crystal Structure Determination of 2. The structure of 2 
was determined by single crystal X-ray diffraction analysis. Summary of the crystal structure and structure refinement for $\mathbf{2}$ are listed in Table 1. A colorless cubic-shaped crystal $\left(0.20 \times 0.20 \times 0.10 \mathrm{~mm}^{3}\right)$ was picked up with paratone oil and mounted on a Siemens SMART CCD diffractometer equipped with a graphite-monochromated $\operatorname{MoK} \alpha \quad(\lambda=$ $0.71073 \AA)$ radiation source and a nitrogen cold stream $(-50$ ${ }^{\circ} \mathrm{C}$ ). For 2 , contributions from disordered solvent molecules were removed by the SQUEEZE routine (PLATON), ${ }^{14}$ and the outputs from the SQUEEZE calculations are attached to each CIF file. All crystallographic data were corrected for Lorentz and polarization effects (SAINT), and empirical absorption corrections based on equivalent reflections were applied (SADABS). The structures were solved by direct methods and refined by the full-matrix least-squares method on $F^{2}$ with appropriate software implemented in the SHELXTL program package. ${ }^{15}$ All the hydrogen atoms were added at their geometrically ideal positions. Crystallographic data for the structure reported here have been deposited with the Cambridge Crystallographic Data Centre (Deposition No. CCDC-807584 for 2). The data can be obtained free of charge at www.ccdc.cam.ac.uk/conts/ retrieving.html (or from the CCDC, 12 Union Road, Cambridge CB2 1EZ, UK; fax: +44 1223 336033; e-mail: deposit@ccdc.cam.ac.uk).

Acknowledgments. This work was supported by the Gachon University research fund of 2013. (GCU-2013R267) We also thank to H. W. Kim and H. Kim for DFT calculation and Connolly surface analysis, respectively.

\section{References}

1. (a) Li, H.; Eddaoudi, M.; O'Keeffe, M.; Yaghi, O. M. Nature 1999, 402, 276. (b) Janiak, C. Dalton Trans. 2003, 2781. (c) James, S. L. Chem. Soc. Rev. 2003, 32, 276. (d) Long, J. R.; Yaghi, O. M. Chem. Soc. Rev. 2009, 38, 1213. (e) Zhou, H.-C.; Long, J. R.; Yaghi, O. M. Chem. Rev. 2012, 112, 673.

2. Herein we use the terms of CPs and MOFs by following the terminology guidelines of coordination compounds recently suggested, Batten, S. R.; Champness, N. R.; Chen, X.-M.: GarciaMartinez, J.; Kitagawa, S.; Öhrström, L.; O'Keeffe, M.; Suh, M. P.; Reedijk, J. CrystEngComm 2012, 14, 3001.

3. (a) Yaghi, O. M.; O'Keeffe, M.; Ockwig, N. W.; Chae, H. K.; Eddaoudi, M.; Kim, J. Nature 2003, 423, 705. (b) Ockwig, N. W.; Delgado-Friedrichs, O.; O'Keeffe, M.; Yaghi, O. M. Acc. Chem. Res. 2005, 38, 176. (c) Long, J. R.; Yaghi, O. M. Chem. Soc. Rev. 2009, 38, 1213. (d) Li, M.; Li, D.; O'Keeffe, M.; Yaghi, O. M. Chem. Rev. 2014, 114, 1343

4. (a) Li, H.; Eddaoudi, M.; O'Keeffe, M.; Yaghi, O. M. Nature 1999, 402, 276. (b) Dybtsev, D. N.; Chun, H.; Kim, K. Angew. Chem. Int. Ed. 2004, 43, 5033. (c) Murray, L. J.; Dincă M.; Long, J. R. Chem. Soc. Rev. 2009, 38, 1294. (d) Sumida, K.; Rogow, D. L.; Mason, J. A.; McDonald, T. M.; Bloch, E. D.; Herm, Z. R.; Bae, T.-H.; Long, J. R. Chem. Rev. 2012, 112, 724. (e) Suh, M. P.; Park,
H. J.; Prasad, T. K.; Lim, D.-W. Chem. Rev. 2012, 112, 835. (f) Mason, J. A.; Veenstra, M.; Long, J. R. Chem. Sci. 2014, 5, 32.

5. (a) Li, J.-R.; Kuppler, R. J.; Zhou, H.-C. Chem. Soc. Rev. 2009, 38, 1477. (b) Li, J. R.; Sculley, J.; Zhou, H.-C. Chem. Rev. 2012, 112, 869. (c) Herm, Z. R.; Bloch, E. D.; Long, J. R. Chem. Mater. 2014, 26, 323 .

6. (a) Kreno, L. E.; Leong, K.; Farha, O. K.; Allendorf, M.; Van Duyne R. P.; Hupp, J. T. Chem. Rev. 2012, 112, 1105. (b) Cui, Y.; Yue, Y.; Qian, G.; Chen, B. Chem. Rev. 2012, 112, 1126.

7. (a) Seo, J.-S.; Whang, D.; Lee, H.; Jun, S. I.; Oh, J.; Jeon, Y. J.; Kim, K. Nature 2000, 404, 982. (b) Banerjee, M.; Das, S.; Yoon, M.; Choi, H. J.; Hyun, M. H.; Park, S. M.; Seo, G.; Kim, K. J. Am. Chem. Soc. 2009, 131, 7524. (c) Yoon, M.; Srirambalaji, R.; Kim, K. Chem. Rev. 2012, 112, 1196. (d) Srirambalaji, R.; Hong, S.; Natarajan, R.; Yoon, M.; Hota, R.; Kim, Y.; Ko, Y. H.; Kim, K. Chem. Commun. 2012, 11650.

8. (a) Hurd, J. A.; Vaidhyanathan, R.; Thangadurai, V.; Ratcliffe, C. I.; Moudrakovski, I. L.; Shimizu, G. K. H. Nat. Chem. 2009, 1, 705. (b) Taylor, J. M.; Mah, R. K.; Moudrakovski, I. L.; Ratcliffe, C. I.; Vaidhyanathan, R.; Shimizu, G. K. H. J. Am. Chem. Soc. 2010, 132, 14055. (c) Yoon, M.; Suh, K.; Kim, H.; Kim, Y; Selvapalam, N.; Kim, K. Angew. Chem. Int. Ed. 2011, 50, 7870. (d) Sahoo, S. C.; Kundu, T.; Banerjee, R. J. Am. Chem. Soc. 2011, 133, 17950. (e) Horike, S.; Umeyama, D.; Inukai, M.; Itakura, T.; Kitagawa, S. J. Am. Chem. Soc. 2012, 134, 7612. (f) Yoon, M.; Suh, K.; Natarajan, S.; Kim, K. Angew. Chem. Int. Ed. 2013, 52, 2688.

9. (a) Kim, H.; Das, S.; Kim, M. G.; Dybtsev, D. N.; Kim, Y.; Kim, K. Inorg. Chem. 2011, 50, 3691. (b) McKinstry, C.; Cussen, E. J.; Fletcher, A. J.; Patwardhan, S. V.; Sefcik, J. Cryst. Growth Des. 2013, 13, 5481 .

10. (a) Serre, C.; Mellot-Draznieks, C.; Surblél, S.; Audebrand, N.; Filinchuk, Y.; Férey, G. Science 2007, 315, 1828. (b) Michaelides, A.; Skoulikaa, S.; Siskosa, M. G.; CrystEngComm. 2008, 10, 817. (c) Wißmann, G.; Schaate, A.; Lilienthal, S.; Bremer, I.; Schneider, A. M. Microporous Mesoporous Mater. 2012, 152, 64. (d) Rajput, L.; Kim, D.; Lah, M. S. CrystEngComm. 2013, 15, 259.

11. (a) Yang, J.; Li, G.-D.; Cao, J.-J.; Yue, Q.; Li, G.-H.; Chen, J.-S. Chem.-Eur. J. 2007, 13, 3248. (b) Xu, H.; Li, Z. Micropor Mesopor. Mat. 2008, 115, 522. (c) Zhang, R.-F.; Wang, Q.-F.; Yang, M.-Q.; Wang, Y.-R.; Ma, C.-L. Polyhedron 2008, 27, 3123. (d) Hernandez-Ahuactzi, I. F.; Cruz-Huerta, J.; Barba, V.; Hopfl, H.; Zamudio-Rivera, L. S.; Beltran, H. I. Eur. J. Inorg. Chem. 2008, 1200. (e) Gurunatha, K. L.; Maji, T. K. Inorg. Chem. 2009, 48, 10886. (f) Lu, J.; Bi, W.-H.; Xiao, F.-X.; Batten, S. R.; Cao, R. Chem.-Asian J. 2008, 3, 542. (g) Zheng, Y.-Z.; Xue, W.; Zhang, W.-X.; Tong, M.-L.; Chen, X.-M.; Grandjean, F.; Long, G. J.; Ng, S.-W.; Panissod, P.; Drillon, M. Inorg. Chem. 2009, 48, 2028. (h) Tian, G.; Zhu, F.; Su, B.-L.; Qiu, S. J. Mater. Sci. 2009, 44, 6576. (i) Lu, J.; Bi, W.; Cao, R. CrystEngComm 2009, 11, 2248.

12. Yoon, M.; Sun, H.-J.; Lee, D.-H.; Park, G. Bull. Korean Chem. Soc. 2012, 33, 3111.

13. (a) Rosi, N. L.; Kim, J.; Eddaoudi, M.; Chen, B.; O'Keeffe, M.; Yaghi, O. M. J. Am. Chem. Soc. 2005, 127, 1504. (b) He, J.; Yu, J.; Zhang, Y.; Pan, Q.; Xu, R. Inorg. Chem. 2005, 44, 9279. (c) Thirumurugan, A.; Cheetham, A. K. Eur. J. Inorg. Chem. 2010, 3823.

14. L. Spek, PLATON, a multipurpose crystallographic tool, Utrecht University, Utrecht, The Netherlands, 2001.

15. Sheldrick, G. M. Acta Cryst. 2008, A64, 112. 